\title{
A Note on Shifts in Turkey's International Trade Pattern*
}

\section{Türkiye'nin Uluslararası Ticaret Yapısındaki Kaymalara Dair Bir Not}

\section{Çağaçan Değer ${ }^{1}$}

Abstract:

It is frequently stated that Turkey's trade orientation has shifted in the last decade away from Europe and more towards the East, specifically Arab countries and Middle East. However, comprehensive presentation of the situation is lacking, causing concern over the validity of the statement. This paper examines the foreign trade of Turkey for years 1995 to 2012. The analysis focuses on a number of country groups and product categories. The analysis confirms the shift away from EU and towards not only Arab countries but Asia as a whole, primarily due to gas imports from Russia. It is observed that Turkey's exports are becoming more focused towards manufactured goods and increasing in technological complexity. An interesting observation is the increase in the share of "commodities and transactions not elsewhere classified", especially with the Arab countries.

Keywords: international trade; Turkey; trade patterns

\section{Introduction}

The importance of international trade is widely recognised. It is a subject in theoretical discussions, policy debates and economic planning. Academicians try to reveal the stylized facts of existing trade and focus on providing theoretical explanations on why trade exists. Issues such as importance of import dependency for developing countries or the necessity of competitive exports for economic development provide fuel for hot policy debates.

Despite rich debate on theory and policy, analyses of large datasets aimed at identifying stylized facts of international trade are relatively lacking (Harris, Konya and Matyas, 2012). Existing studies focus on bilateral flows in large datasets (Feenstra, Lipsey and Bowen, 1997; Rose, 2004). Some studies focus on specific countries or country groups such as Africa (Easterly and Reshef, 2010), emerging economies (Hanson, 2012) or isolated countries such as Myanmar and North Korea (Oh, 2011). These studies contribute by identifying existing trade patterns, providing solid input for policy debates and directing

* Dedicated to the memory of late Şuayip Durak.

1 Yard. Doç. Dr. Ege Üniversitesi, îktisat Bölümü 


\section{0 Çağaçan Değer}

researchers to adopt appropriate theoretical approaches for a given country or country group.

Studies that focus on Turkey are primarily interested in Turkey-EU trade (Gros and Selcuki, 2013; Neyapti, Taskin and Ungor, 2007; Yilmaz, 2003). Works that are relatively more comprehensive in terms of country coverage (Yukseler and Turkan, 2008; Yilanlioglu, 2008) do not cover the recent years, and thus fall short of considering more recent shifts in Turkey's international trade. Cinar and Goksel (2010) analyze diversification and stability of Turkey's exports during 2000s. For the analysis ends in 2007, more recent developments are not observed. Utkulu (2008) lists the countries and product groups that lead in Turkey's foreign trade; but, the dimensions of product groups and country groups are not crossed. An analysis of trade by both country groups and commodities is provided by a committee of experts that contribute to the economic planning process of the Ministry of Development (SPO, 2007), but the analysis does not extend beyond year 2005. The most comprehensive analysis is conducted by DTM (2011) where country and product category classifications are considered simultaneously. However, DTM (2011) covers up to year 2010, at best, and has difficulty covering the most recent trends.

The analysis of the existing literature reveals that the literature falls short in either one of three dimensions: They either do not cover the most recent years, or do not go into country detail, or do not have adequate product group coverage. The aim of this study is to analyze how Turkey's imports and exports have shifted in terms of country groups and product categories. The adopted methodology is straightforward: evolution of the shares of country groups and product categories in imports and exports are examined for 1995 to 2012, utilizing trade data from UNCTAD. The study contributes as follows i) a relatively more complete trade partner sample is considered, ii) more detailed product categories are considered, and, iii) time dimension is also extended to more recent years. It is this last item, the inclusion of recent years, that enables this manuscript to identify certain key events such as the increasing importance of "commodities and transactions, n.e.c." in Turkey's international trade.

Next section presents observations on Turkey's international trade employing product and country aggregations, where product category aggregations are based on SITC Rev 3 classification. Last section summarizes the observations and concludes. 


\section{Analysis of Turkey's International Trade}

The analysis starts with examining two basic dimensions of trade: the distribution to various country groups and the distribution to various product categories. Considered country groups are Turkic Republics, BRIC, Middle East countries, the Arab World (which is an extension of the Middle East group), the European Union, American countries, Southeast Asian countries, Central Asian countries and African countries. An explicit list of countries in each group is presented in Appendix A. Product categories are based on single digit SITC Rev 3 categories, detailed when deemed necessary. For technology and skill content of trade, UNCTAD's classification based on SITC Rev 3 is adopted. Graphical representations for shares of product and country groups in Turkey's international trade are presented in Appendix B.

Figures B1 and B2 show the shares of various country groups in Turkey's exports. Shares of various groups in Turkey's imports are displayed in Figures B3 and B4. A brief examination of these figures reveals that the share of EU in Turkey's both imports and exports have been falling steadily since 1995. The share of EU in Turkey's exports has been nearly steady at $60 \%$ of total exports. However, by 2012 , this share falls to $40 \%$ in 2012. A similar picture is observed for imports as well. The share of EU countries in Turkey's imports falls from 50\% in 1995 to 40\% in 2012 as well. An other shift in Turkey's exports appears to have occurred to the Middle East and Arab countries. Regarding imports; especially BRIC countries display a rise in import shares. Both Central and East Asian countries also display a similar increase in imports of Turkey. When broken down to countries, the increasing shares are due to increased imports from Russia and China.

Figures B5 and B6 show the shares of various commodity groups in Turkey's exports; corresponding import shares are presented in Figures B7 and B8. Regarding exports, the share of "manufactured goods" has a stable 30\% share throughout the considered time period. The share of "machinery and transport equipment" has been increasing from 1995 to mid 2000s. The shares of "miscellaneous manufactured articles" and "food and live animals" are observed to be decreasing from 1995 to 2012. An interesting observation is that the share of "commodities and transactions n.e.c." shows a significant increase, especially after 2005. This corresponds to code 9 of SITC Rev 3, content of which is unclassified postal packages, special transactions and unclassified commodities, coins that are not gold or legal tender, and non-monetary gold. Lack of detailed data prevents detailed analysis of this group but gold trade originating from the Middle East is a likely candidate. 
Figures B7 and B8 show for imports that the shares of most commodity groups are stable. Noticeable changes are in the shares of "machinery and transport equipment" and "commodities and transactions n.e.s." in imports. As "machinery and transport equipment" imports fall, imports of "commodities and transactions n.e.s." are on the rise.

Figure B9 shows export shares of manufactures in terms of technological content. From 1995 to 2012, Turkey's manufactured good exports have shifted away from "labor intensive and resource intensive manufactures" towards "medium skill and technology intensive manufactures". This implies an increase in competitive ability of more technology oriented manufacturing sectors in the global trade arena. On the other hand, import profile regarding manufactures does not appear to have changed in the considered time period; see Figure B10. Turkey's manufactured good imports are dominated by medium and high skill technology intensive manufactures; pointing to a lack of domestic productive capacity in these product categories.

Next consider two specific country groups: EU and Arab Countries. The reason for this focus is displayed in Figures B1 to B4; Turkey's trade shifts from EU to Arab countries. Figures B11 and B12 show that exports to EU are primarily "miscellaneous manufactured articles", "manufactured goods", "machinery and transport equipment" and "food and live animals". The shares of "food and live animals" and "miscellaneous manufactured goods" in exports have been falling steadily. There is a considerable increase in the share of "machinery and transport equipment" in exports.

Figures B13and B14 show the shares of various commodity groups in Turkey's imports from EU. There is not a clear trend shift and it is difficult to identify which groups are leading in terms of import shares. Thus the mean shares for each category group for the 1995-2012 period is considered. The leading sector in Turkey's imports from EU is "machinery and transport equipment", with an average import share of $29 \%$ for the time period from 1995 to 2012 . Following product categories of importance are "chemicals and related products n.e.s." (23\%), "manufactured goods" (18\%), and, "crude materials, inedible, except fuels" (10\%).

In order to examine manufacture imports from EU28 counties in more detail, assume that 1 digit SITC Rev 3 sectors 
covered under manufactures are coded 6 (manufactured goods classified by material), 7 (machinery and transport equipment) and 8 (miscellaneous manufactured articles). These sectors consistently account for more than $60 \%$ of imports from EU28. The largest share within this group belongs to "machinery and transport equipment" sector, with a consistent share of more than $60 \%$ in the 1995 to 2012 period. Further details can be observed from Figures B15 and B16. Figure B15 shows the sectors with a relatively lower share in the manufacture imports of Turkey from EU. The sectors with relatively higher shares are displayed in Figure B16. An examination of these two figures underline that the shares of "power generating machinery and equipment" and "road vehicles, including air-cushion vehicles" sectors have been steadily on the rise as of year 2000. This is most likely a reflection of outsourcing of production from Europe to Turkey; especially the construction of light commercial vehicles.

Finally consider Turkey's trade with Arab countries, which are primarily in the Middle East. The shares of various product categories in Turkey's exports to Arab countries is shown in Figures B17 and B17. It is observed that exports to Arab countries are primarily "manufactured goods", "machinery and transport equipment", "food and live animals" and "miscellaneous manufactured articles". The share of manufactures in exports to Arab countries is relatively stable. However, share of "food and live animals" falls through time from $25 \%$ to about $10 \%$. The share of "commodities and transactions n.e.s." rises; this category jumps especially in the last few years to more than $10 \%$.

Product group distribution of imports from Arab countries is presented in Figures B19 and B20. There is an interesting shift in Turkey's imports from Arab countries, globally recognized providers of oil. In mid 1990s, nearly all of Turkey's imports from the Arab Countries used to be "mineral fuels, lubricants and related materials". The share of this product group in imports falls dramatically during the last two decades. The shares of "chemicals and related products" and "manufactured goods" rise. Also, the rise in "commodities and transactions n.e.s." is considerable.

The SITC Rev 3 category of “mineral fuels, lubricants and related materials" implies petroleum products. One's initial expectation would be to see Middle Eastern and Arab countries to play a dominant role regarding imports in this category of goods. If Turkey's primary supplier of these goods is not the Middle East anymore, then where do they come from? A brief country by country examination of data reveals that the major import partners of Turkey in this product category are Europe 


\section{4 Çağaçan Değer}

(especially Italy and Greece) and BRIC (especially Russia).

Russia is well established as an exporter of both petroleum and processed petroleum products; high imports from Russia is therefore not surprising. From Italy and Greece, the highest share of imports in the "mineral fuels, lubricants and related materials" product category is in the "petroleum oils or bituminous minerals $>70 \%$ oil" product category, which corresponds to SITC Rev 3 code of 334 . The share of product category 334 in category 3 is $97 \%$ for Greece and $80 \%$ for Italy on average for the 1995 to 2012 time period. The product category "petroleum oils or bituminous minerals $>70 \%$ oil" includes light oils, kerosene and other medium oils, gas oils, fuel oils n.e.s, and lubricating petroleum related oils. These are refined petroleum products; conclusion is that Italy and Greece supply considerable refined petroleum products to Turkey.

Italy has a reputation as the supplier of refined petroleum products; according to hydrocarbons-technology.com (2013), Italy holds world's $7^{\text {th }}$ largest oil refining capacity. Greece, however, is an unexpected exporter of refined petroleum products. A brief examination of Greece's petroleum refinery industry shows that the increasing importance of petroleum refining in Greece is a most recent development. The share of refined petroleum products in Greek exports has been rising, especially after 2010. According to UNCTAD data, the share of "petroleum oils or bituminous minerals $>70 \%$ oil" in Greece's exports was about $5.5 \%$ in 1995 . This share increases to $26 \%$ in 2011 and reaches $37 \%$ in 2013 . Reuters (2013) highlights, through the example of Hellenic Petroleum, the rise of refined petroleum products industry after the recent crisis in Greece. Thus Turkey appears to have benefited from the growing refined petroleum products industry in Greece.

Central Asia, also has a large share regarding fuels as a group; but this is primarily due to inclusion of Russia in the Central Asia group. Turkic Republics do not have a high share. This is a reflection of Turkey's increasing use of natural gas, imported primarily from Russia.

\section{Conclusion}

Identified facts on Turkey's international trade are summarized as follows:

First observation is that Turkey's trade has shifted away from EU towards Arab countries. This can be regarded as a result of trade policies in the last decade. Politicians visiting African and Middle Eastern countries have been accompanied by businessmen. Established relations appear to be be reflected in trade. 
An other identified fact is that imports have shifted away from EU to Asia, specifically to Russia and China. The shift to Russia is primarily due to petroleum related products, especially natural gas. China has been on the rise as an exporter of cheap manufactured goods; Turkey is being influenced by this rise.

Regarding commodity groups; the share of "machinery and transport equipment" in exports appear to increase whereas "food and live animal" exports are falling. This is most likely a reflection of the shift in agricultural support policies; direct income support replacing output related support implies less output for exports. Turkey, especially Bursa, became a production base for vehicles. Car and light commercial vehicles are being produced in Turkey to be sold in European market. This is reflected in EU-Turkey trade as well: Exports to EU have been shifting away from "food and live animals" towards "machinery and transport equipment". Distribution of imports from EU to various product categories is relatively stable; major items in imports from EU are manufactured goods.

"Machinery and transportation equipment" import share is falling. As Turkey becomes the production base for transportation vehicles, imports are falling. On the other hand, the share of "commodities and transactions n.e.s." in both imports and exports is on the rise. This is most likely a reflection of gold trade with the Middle East, especially Iran. Due to sanctions on using Euro and Dollar with Iran, Turkey uses gold as an intermediary to purchase natural gas from Iran, with the additional cost of raising tensions with the USA (Ergin, 2013; Parkinson and Solomon, 2012; Srivastava and Finkel, 2014; Dubowitz, Ziemba and Clark, 2014).

Manufactured good exports have become more oriented towards medium skill and technology intensive goods, rather than labor intensive and resource intensive goods. Manufacture imports are dominated by medium to high skill, technology intensive goods. Turkey's manufactured goods production process appears to be increasing in technological content; this is reflected in trade patterns.

Turkey's exports to Arab countries are predominantly manufactured goods. Imports from these countries used to be mineral fuels; however, recently imports of fuels has shifted towards other countries. Especially Russia is now a major supplier for Turkey, mostly due to Turkey's increasing use of natural gas.

An interesting observation is the increasing share of "commodities and transactions n.e.s." sector in Turkey's trade, especially with the Arab countries. There is little to no detailed data on this sector and sectoral definitions are vague. But, 


\section{6 Çağaçan Değer}

this item has reached and exceeded $10 \%$ in some years. Such a large share needs to be examined more closely; this a task is possible only through a better classification of trade data. Specifically, it must be considered whether this group of products is actually a reflection of trade in other product categories or whether there are bad bookkeeping practices.

This study confirms the shift of Turkey's trade away from EU and towards near or far Asia. Turkey is becoming more of a manufactures exporter rather than; whether the technology content of these exports are adequate is open to debate. Thus there is room for improvement in technological content of Turkey's exports. 


\section{References}

Cinar, Y. and Goksel T. (2010). Ihracatta bolgesel cesitlendirme ve istikrar. Ankara Universitesi SBF Dergisi. 2(65):29-57.

DTM (2011). Kuresel Ticarette Turkiye'nin Yeniden Konumnlandirilmasi: Dis Ticarette Yeni Rotalar. Address: http://tinyurl.com/kwbvmvn Access Date: 11 August 2014.

Dubowitz, M., Ziemba, R. and Clark, G. (2014). Turkey exploits Iran's golden loophole. In Gartenstein-Ross, D. and Schanzer, E. (eds). Allies, Adversaries and Enemies: America's Increasingly Complex Alliances. FDD Press. Washington DC.

Easterly, W. and Reshef, A. (2012). African export successes: Surprises, stylised facts and explanations. NBER Working Paper No 16597.

Ergin, E. (2013, January 4). Turkish gold exports rise 800 pct on demand from Iran. Reuters. Address: http://tinyurl.com/oc6423n Access Date: 15 August 2014.

Feenstra, R.C., Lipsey,R.E. and Bowen, H.P. (1997). World trade flows, 1970-1992, with production and tariff data, NBER Working Paper No 5910.

Gros, D. and Selcuki, C. (2013). The changing structure of Turkey's trade and industrial competitiveness: Implications for the EU. Centre for European Studies (CEPS) Working Paper Series No 03.

Hanson, G.H. (2012). The rise of the middle kingdoms: Emerging economies in global trade. NBER Working Paper No 17961.

Harris, M. N., Konya, L. and Matyas, L. (2012). Some stylized facts about international trade flows. Review of International Economics. 20(4): 781-792.

hydrocarbons-technology.com (2013) The 10 biggest oil refining countries. Address: http://tinyurl.com/na4par7 Access Date: 13 August 2014.

Neyapti, B., Taskin, F. and Ungor, M. (2007). Has European Customs Union Agreement really affected Turkey's trade?. Applied Economics. 39(16): 2121-2132.

Oh, J. (2011). International trade of isolated countries: The case of Myanmar and North Korea. European Regional Science Association Conference Paper. Address:http://tinyurl.com/mc9wxmh Access Date: 29 June 2014.

Parkinson, J. and Solomon, J. (2012, November 30). US bears down on Turkey's gold link to Iran. Wall Street Journal. Address: http://tinyurl.com/m95tme5 Access Date: 15 August 2014.

Reuters (2013). Greek refiner Hellenic's darkest days over as oil options grow. Address: http://tinyurl.com/mdvl3xg Access Date: 13 August 2014.

Rose, A.K. (2004). Do we really know that the WTO increases trade? American Economic Review. 94(1):98-114.

SPO (2007). 9. Kalkinma Plani 2007-2013 Dis Ticaret Ozel Ihtisas Komisyonu Raporu. Devlet Planlama Teskilati Yayin No DPT:2705-OIK:660. Devlet Planlama Teskilati: Ankara.

Srivastava, M. and Finkel, I. (2014, June 26). Bling for minister mastermind greased secret Turkey gold trade. Bloomberg. Address: http://tinyurl.com/kt4ujok Access Date: 15 August 2014.

Utkulu, U. (2008). Türkiye'de dış ticaretin gelişimi ve yapısal değişim. In Utkulu, U. and Aydemir, İ. (eds) Türkiye'de Dış 


\section{8 Çağaçan Değer}

Ticaret İşlemleri ve Uygulaması: Teoriden Pratiğe. İkinci Baski. Gazi Kitabevi.

Yilanlioglu, Z. (2008). Türkiye'nin dış ticaretinin yapısal dönüşümü: 1980-2007. Unpublished Masters Thesis. Institute of Social Science, Suleyman Demirel University: Isparta.

Yilmaz, B. (2013). Turkey's competitiveness in the European Union: A comparison with five candidate countries - Bulgaria, the Czech Republic, Hungary, Poland, Romania and the EU15. Ezoneplus Working Paper No 12.

Yukseler, Z. and Turkan, E. (2008). Türkiye'nin üretim ve dış ticaret yapısında dönüşüm: Küresel yönelimler ve yansımalar. TÜSİAD Yayın No: TÜSİAD-T/2008-02/453. 


\section{Appendices:}

Appendix A: Country Lists

\begin{tabular}{|c|c|c|c|c|c|c|c|c|}
\hline $\begin{array}{l}\text { Turkic } \\
\text { Republics } \\
\end{array}$ & BRIC & $\begin{array}{l}\text { Middle } \\
\text { East }\end{array}$ & Arab World & $\begin{array}{l}\text { European } \\
\text { Union }\end{array}$ & America & $\begin{array}{l}\text { Southeast } \\
\text { Asia }\end{array}$ & $\begin{array}{l}\text { Central } \\
\text { Asia }\end{array}$ & $\underline{\text { Africa }}$ \\
\hline Azerbaijan & Brazil & Bahrain & Algeria & Austria & Argentina & China & $\begin{array}{l}\text { Russian } \\
\text { Federation }\end{array}$ & Botswana \\
\hline Kazakhstan & China & Cyprus & Bahrain & Belgium & Brazil & $\begin{array}{l}\text { China, } \\
\text { Hong Kong } \\
\text { SAR }\end{array}$ & Azerbaijan & Cameroon \\
\hline Kyrgyzstan & India & Egypt & Comoros & Bulgaria & Canada & $\begin{array}{l}\text { China, } \\
\text { Taiwan } \\
\text { Province of }\end{array}$ & Georgia & Cape Verde \\
\hline $\begin{array}{l}\text { Turkmenista } \\
\mathrm{n} \\
\end{array}$ & $\begin{array}{l}\text { Russian } \\
\text { Federatio } \\
\text { n }\end{array}$ & $\begin{array}{l}\text { Iran } \\
\text { (Islamic } \\
\text { Republic of) }\end{array}$ & Djibouti & Croatia & Chile & India & Kazakhstan & $\begin{array}{l}\text { Central } \\
\text { African } \\
\text { Republic }\end{array}$ \\
\hline \multirow[t]{10}{*}{ Uzbekistan } & & Iraq & Egypt & Cyprus & Colombia & Indonesia & $\begin{array}{l}\text { Turkmenista } \\
\mathrm{n}\end{array}$ & Chad \\
\hline & & Israel & Iraq & $\begin{array}{l}\text { Czech } \\
\text { Republic }\end{array}$ & Mexico & Japan & Ukraine & Congo \\
\hline & & Jordan & Jordan & Denmark & United States & $\begin{array}{l}\text { Korea, } \\
\text { Republic of }\end{array}$ & Uzbekistan & Côte d'Ivoire \\
\hline & & Kuwait & Kuwait & Estonia & & Pakistan & & $\begin{array}{l}\text { Dem. Rep. Of } \\
\text { the Congo }\end{array}$ \\
\hline & & Lebanon & Lebanon & Finland & & Philippines & & Egypt \\
\hline & & Oman & Libya & France & & Singapore & & Ethiopia \\
\hline & & $\begin{array}{ll}\text { State of } \\
\text { Palestine }\end{array}$ & Mauritania & Germany & & Thailand & & Ghana \\
\hline & & Qatar & Morocco & Greece & & Vietnam & & Kenya \\
\hline & & $\begin{array}{l}\text { Saudi } \\
\text { Arabia }\end{array}$ & Oman & Hungary & & & & Libya \\
\hline & & $\begin{array}{l}\text { Syrian Arab } \\
\text { Republic }\end{array}$ & $\begin{array}{l}\text { State } \\
\text { Palestine }\end{array}$ & Ireland & & & & Mauritania \\
\hline
\end{tabular}




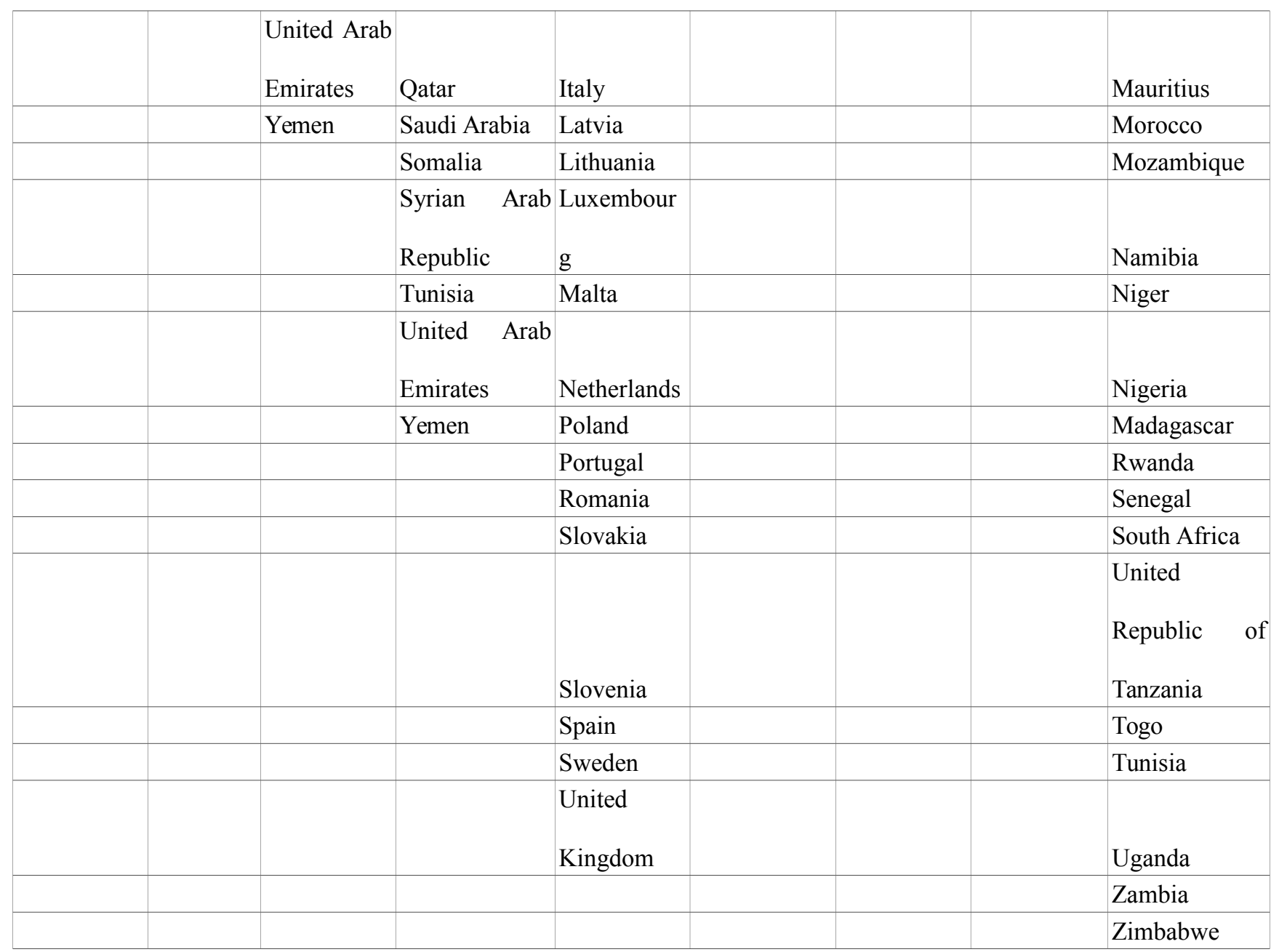


Appendix B: Shares of countries and product groups in Turkey's imports and exports

Figure B1: Share of Country Groups in Turkey's Exports



Source: Author's compilation based on UNCTAD data.

Figure B2: Share of Country Groups in Turkey's Exports 


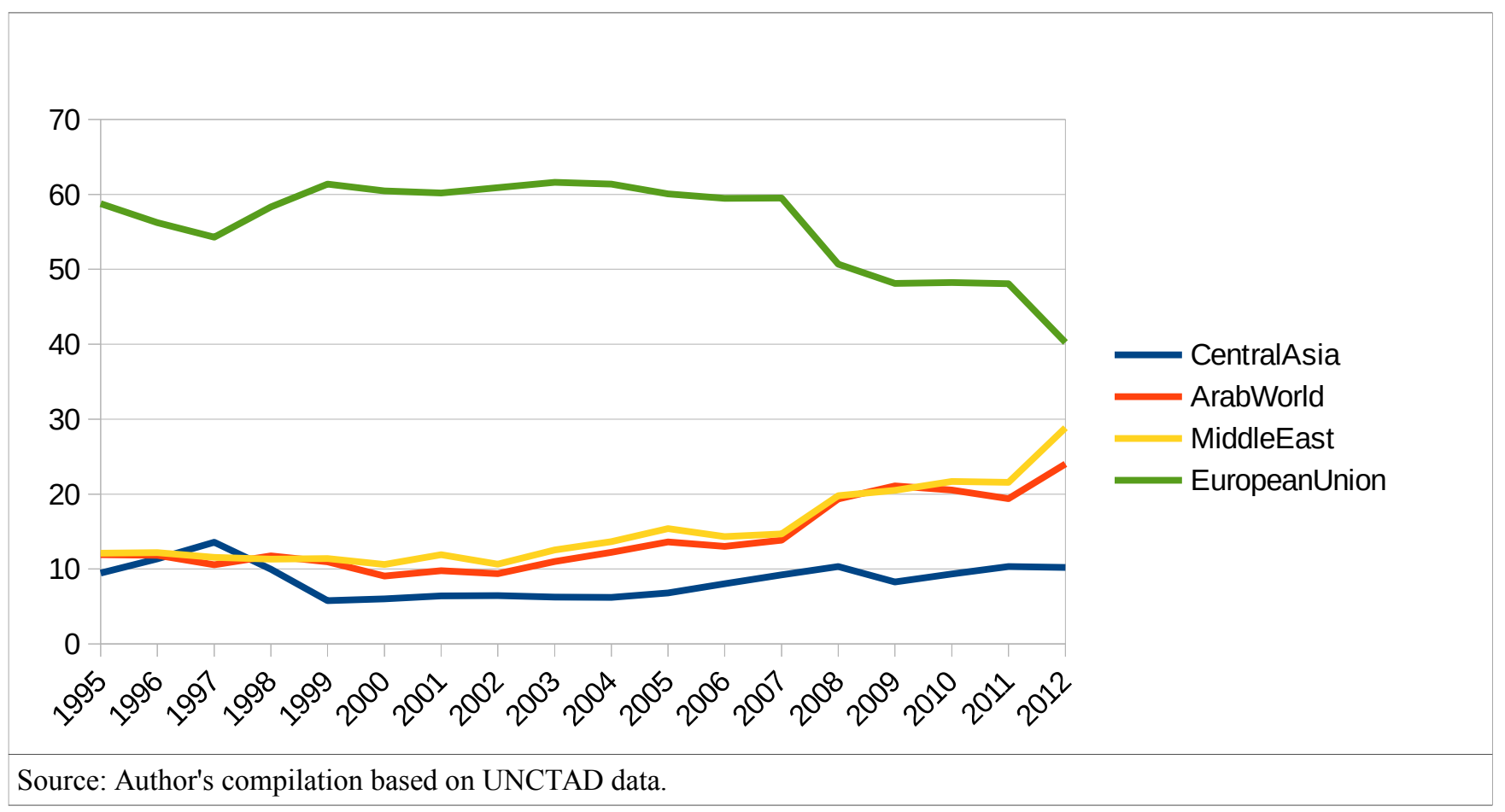

Figure B3: Share of Country Groups in Turkey's Imports




Source: Author's compilation based on UNCTAD data.

Figure B4: Share of Country Groups in Turkey's Imports

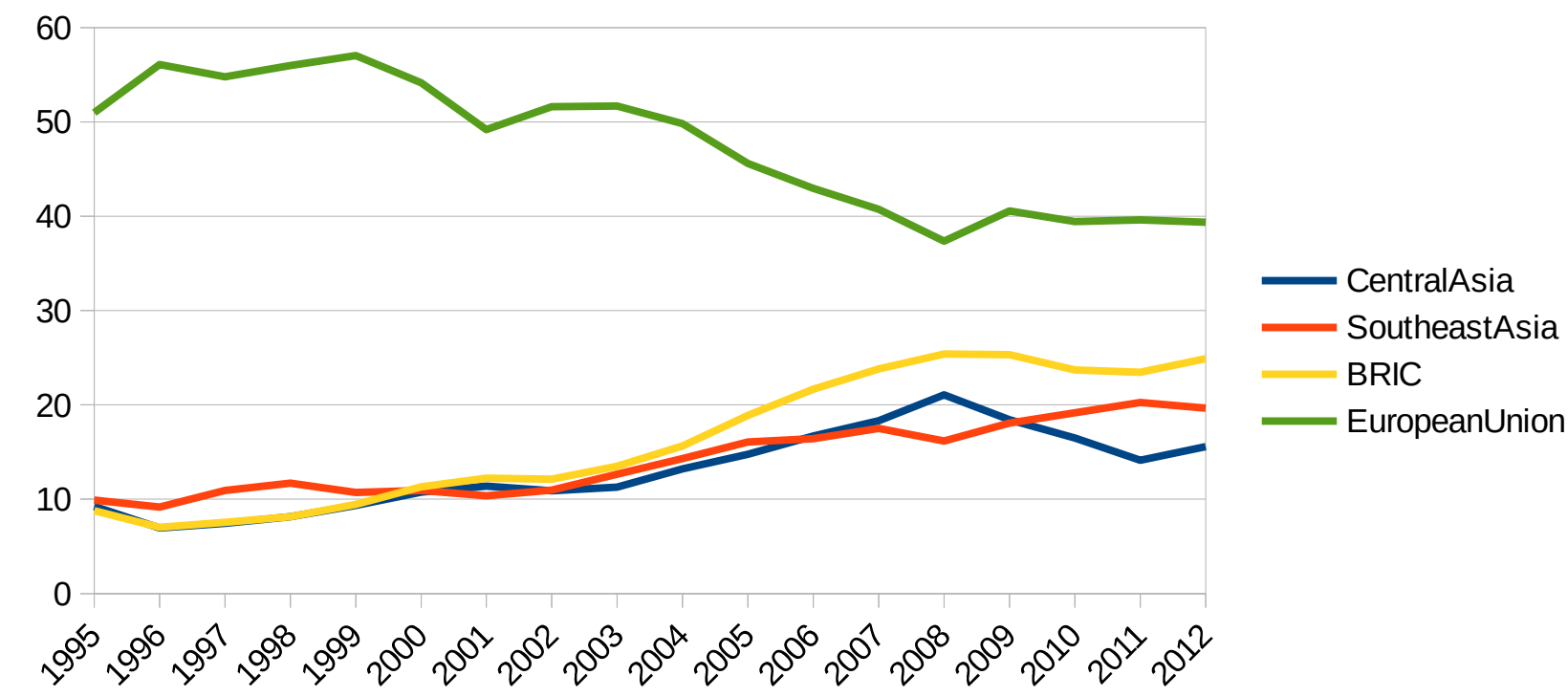

Source: Author's compilation based on UNCTAD data. 
Figure B5: Share of Commodity Groups in Turkey's Exports



- Animal and vegetable oils, fats and waxes

Beverages and tobacco

Commodities and transactions, n.e.s.

Crude materials, inedible, except fuels

Mineral fuels, lubricants and related materials

Source: Author's compilation based on UNCTAD data.

Figure B6: Share of Commodity Groups in Turkey's Exports 


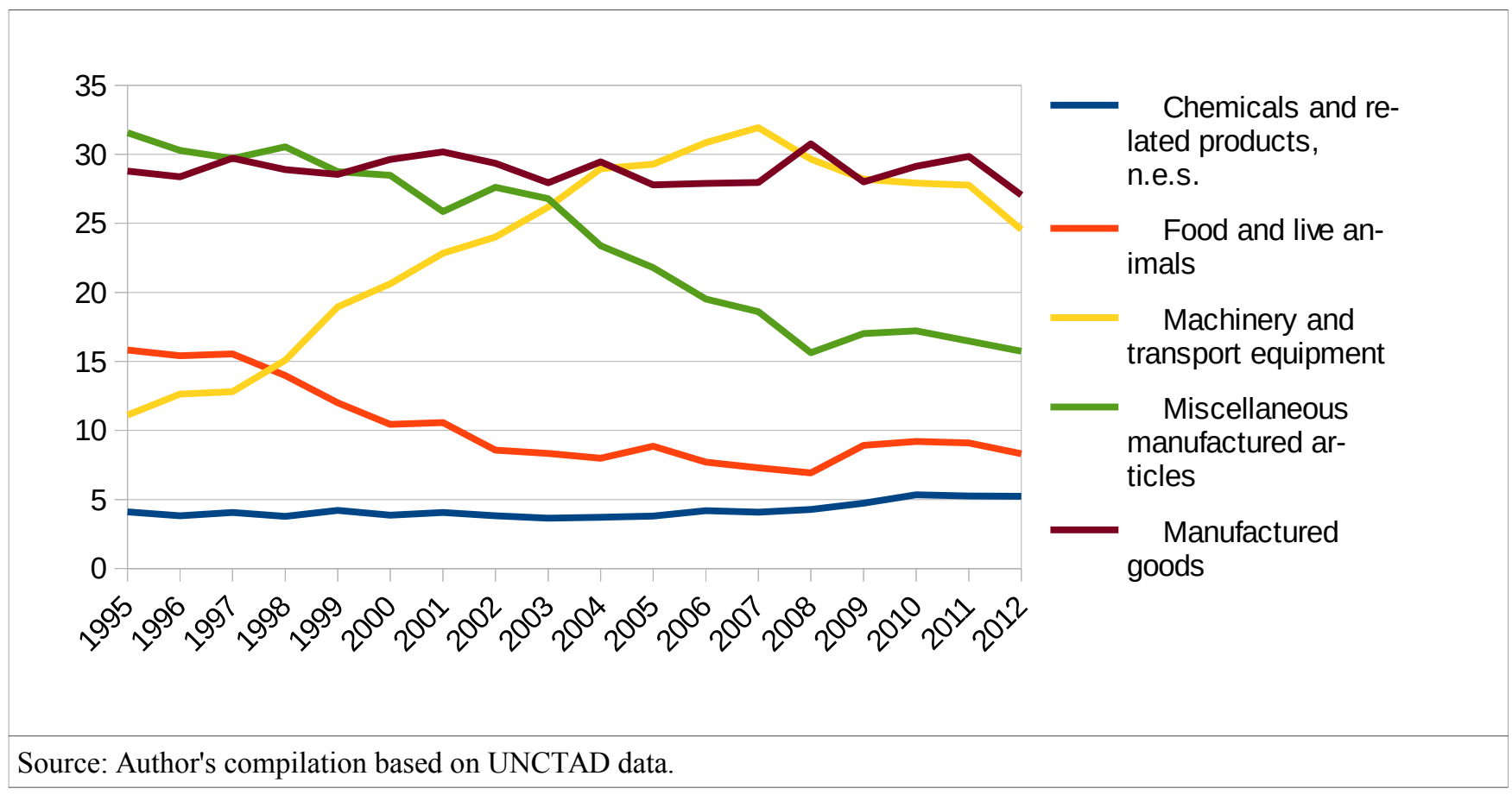


Figure B7: Share of Commodity Groups in Turkey's Imports

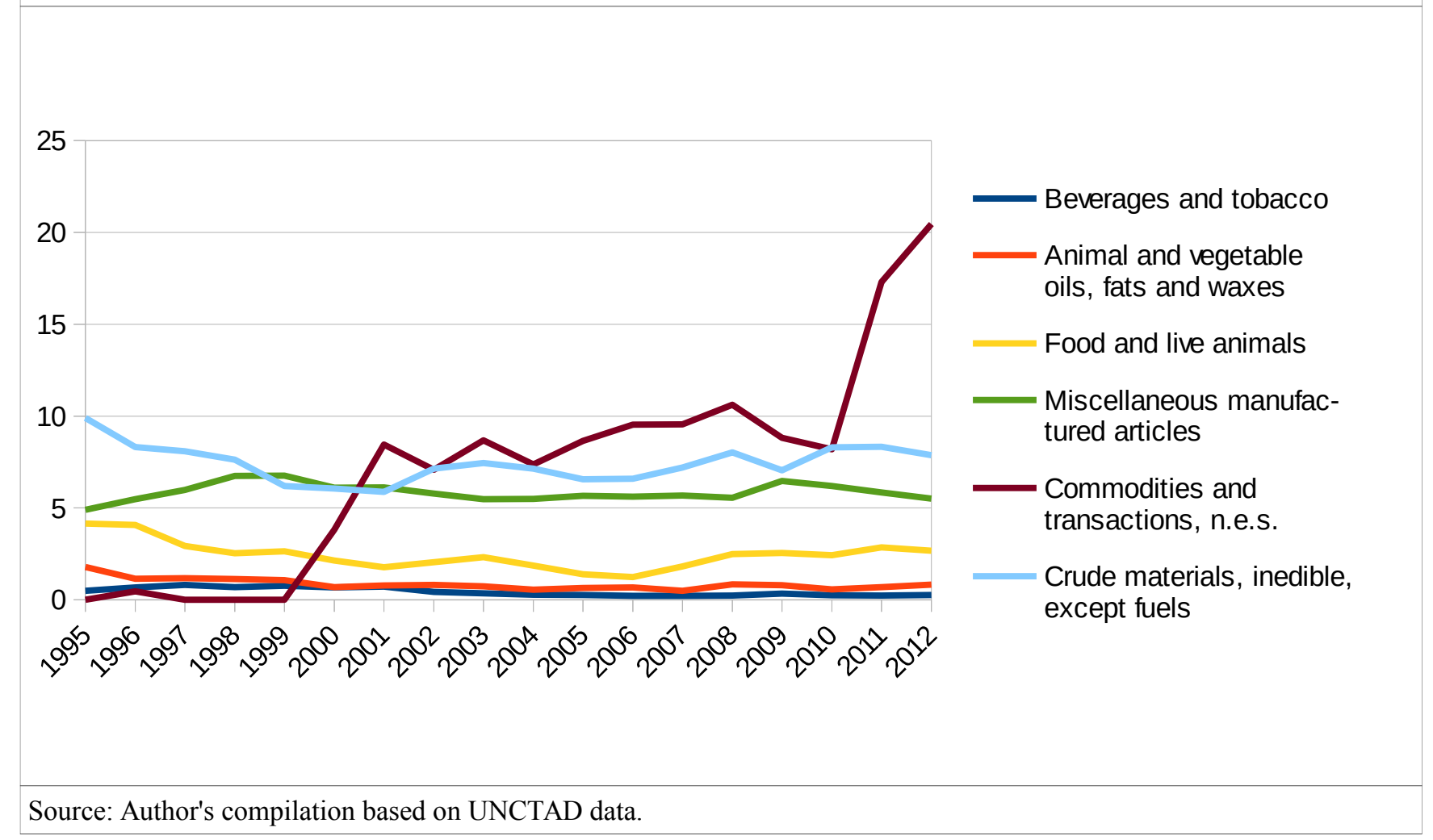

Figure B8: Share of Commodity Groups in Turkey's Imports 


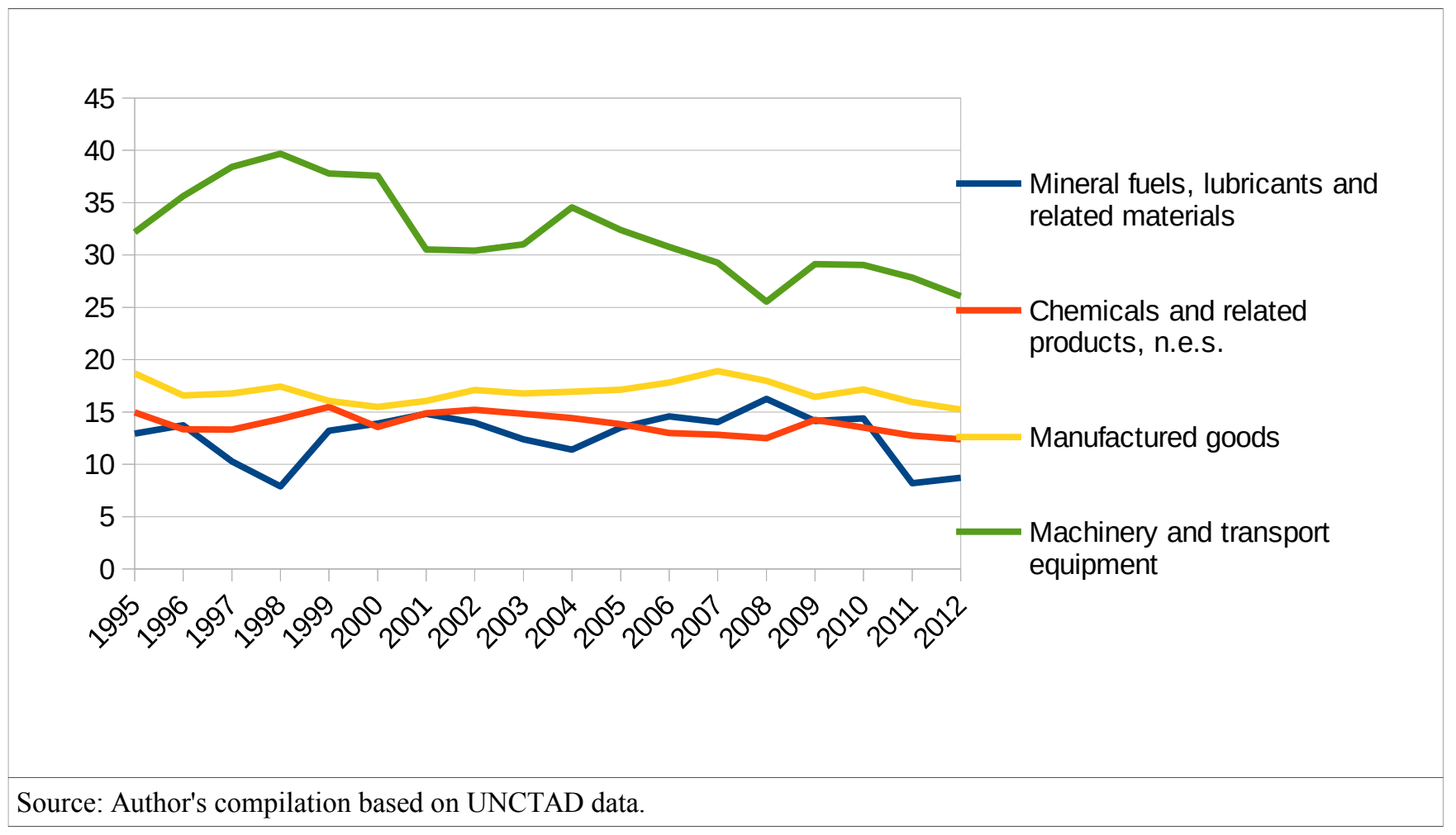


Figure B9: Technology Content of Turkey's Manufacture Exports



Source: Author's compilation based on UNCTAD data.

Figure B10: Technology Content of Turkey's Manufacture Imports 





Figure B11: Distribution of Exports to EU

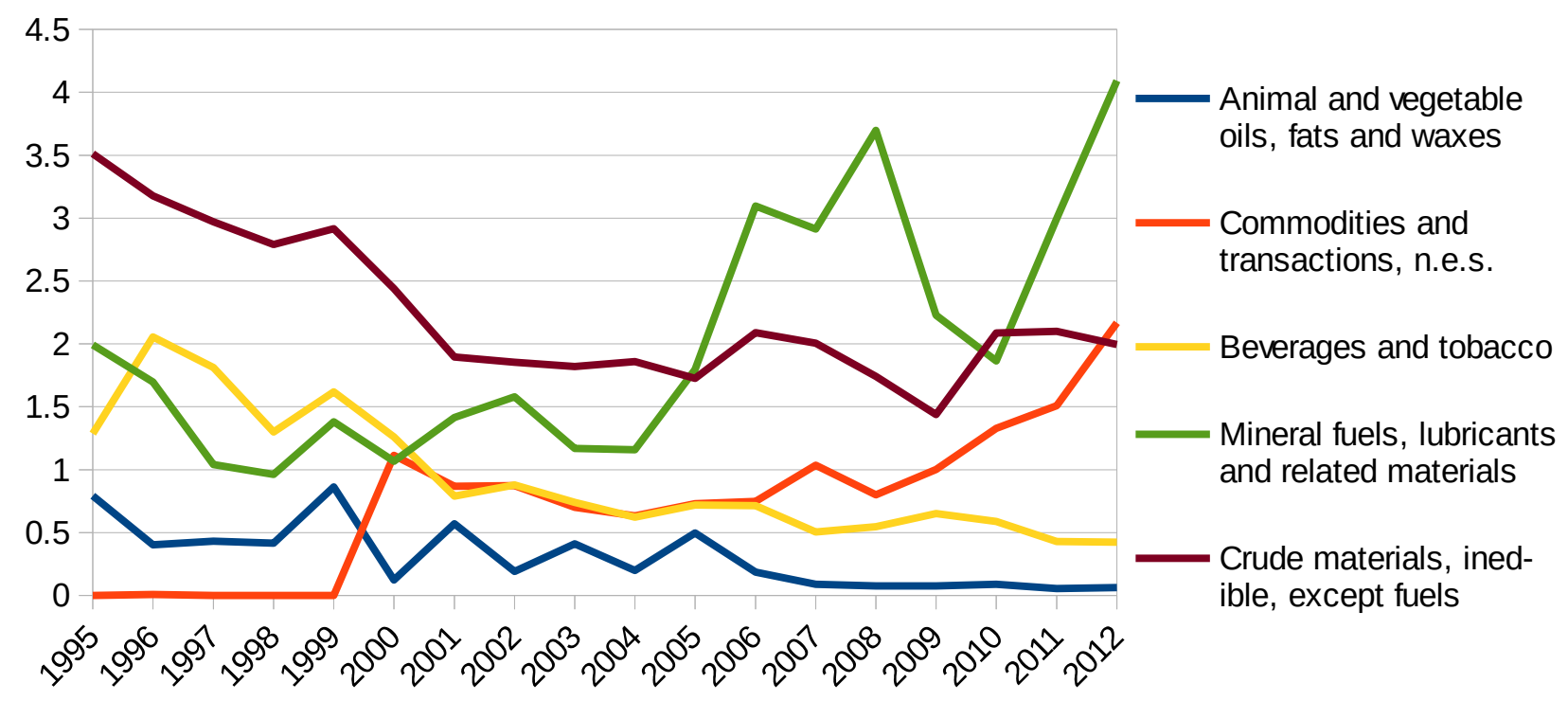

Source: Author's compilation based on UNCTAD data.

Figure B12: Distribution of Exports to EU

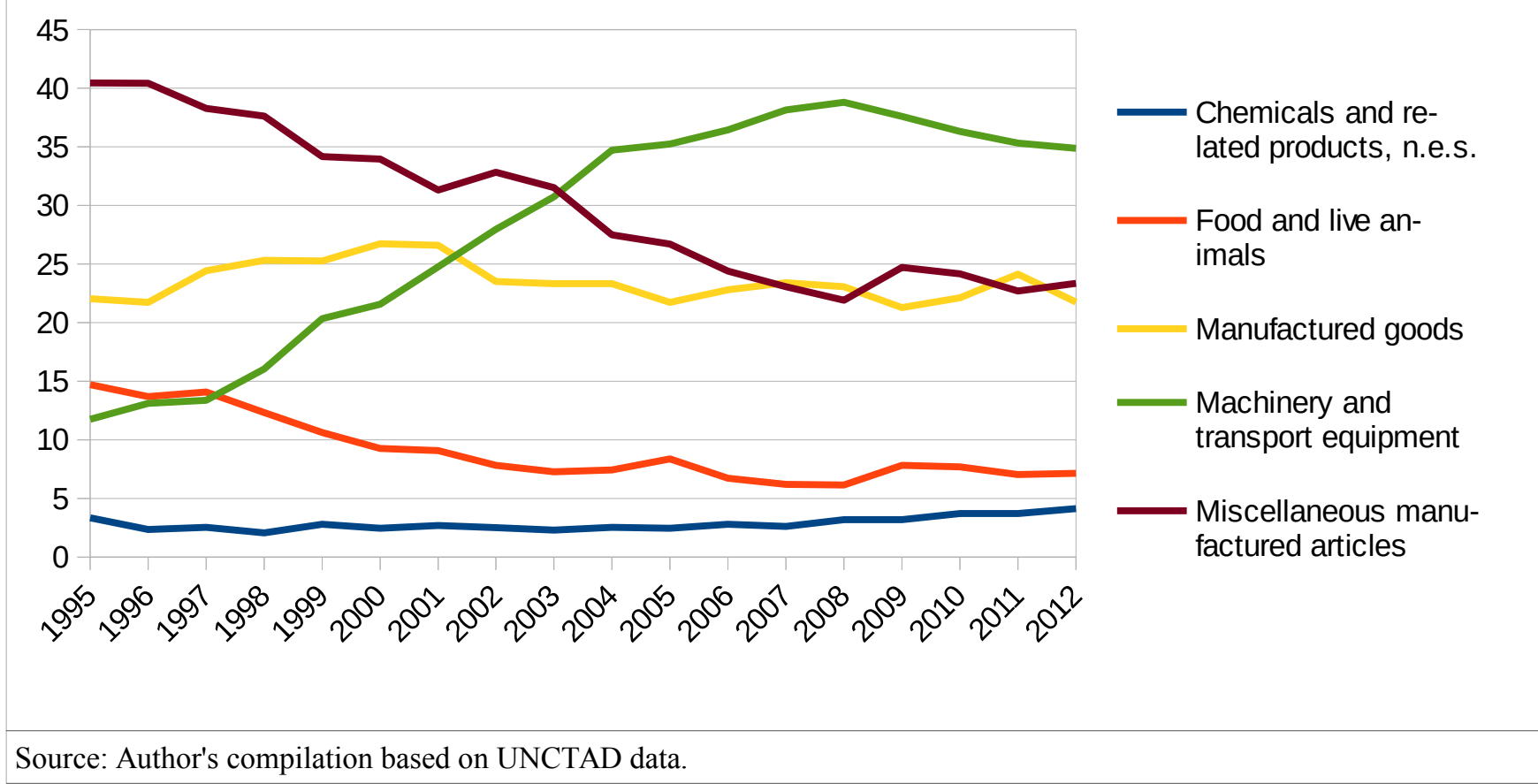


31 Ege Stratejik Araştırmalar Dergisi 
Figure B13: Distribution of Imports from EU

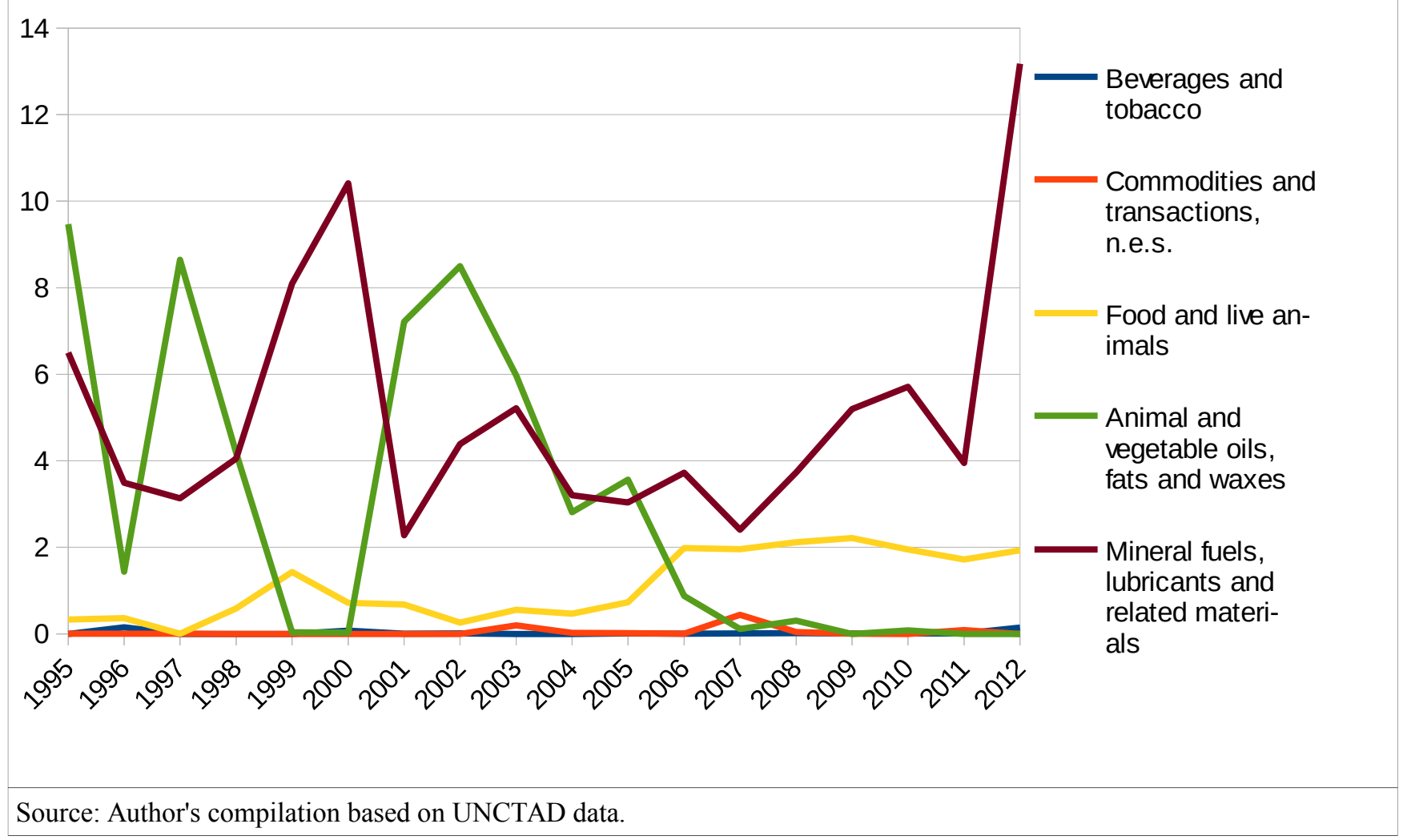

Figure B14: Distribution of Imports from EU 


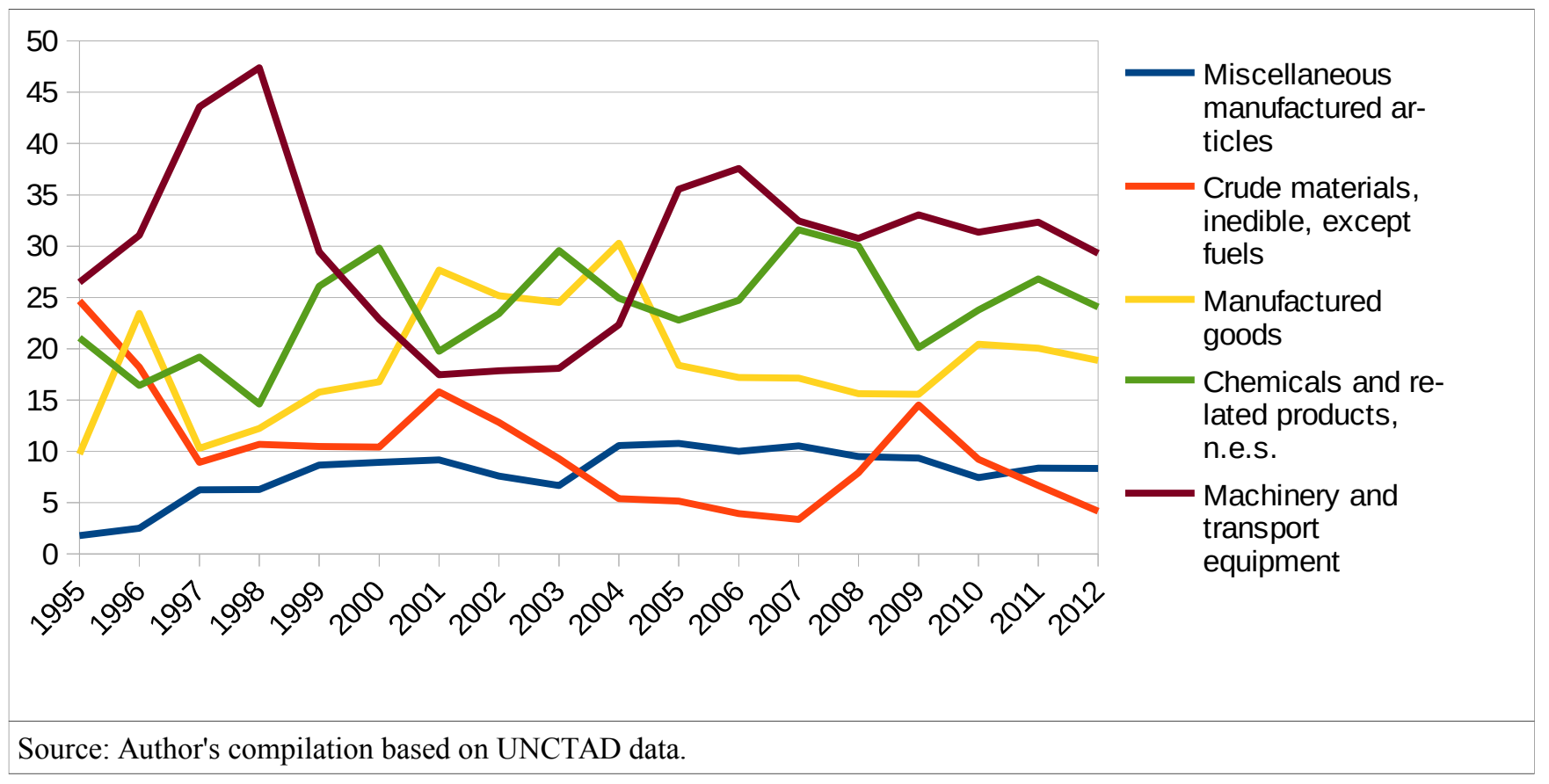


Figure B15: Distribution of Manufactures Imports from EU


Power generating machinery and equipment
Metalworking machinery
Office machines and automatic data-pro- cessing machines
- Telecommunications and sound-recording and reproducing ap- paratus and equip- ment
Other transport equipment

Source: Author's compilation based on UNCTAD data.

Figure B16: Distribution of Manufactures Imports from EU 


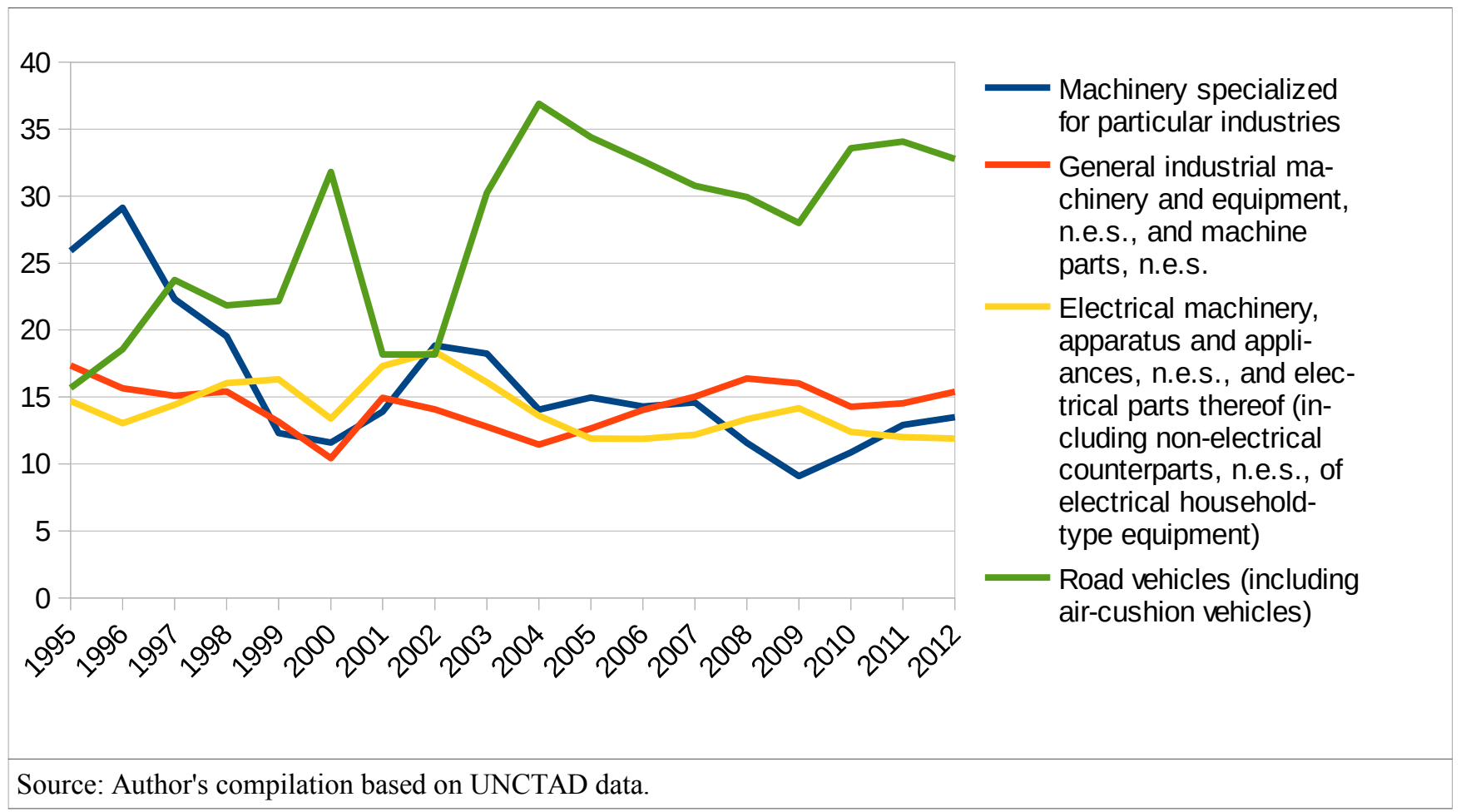


Figure B17: Distribution of Exports to Arab Countries

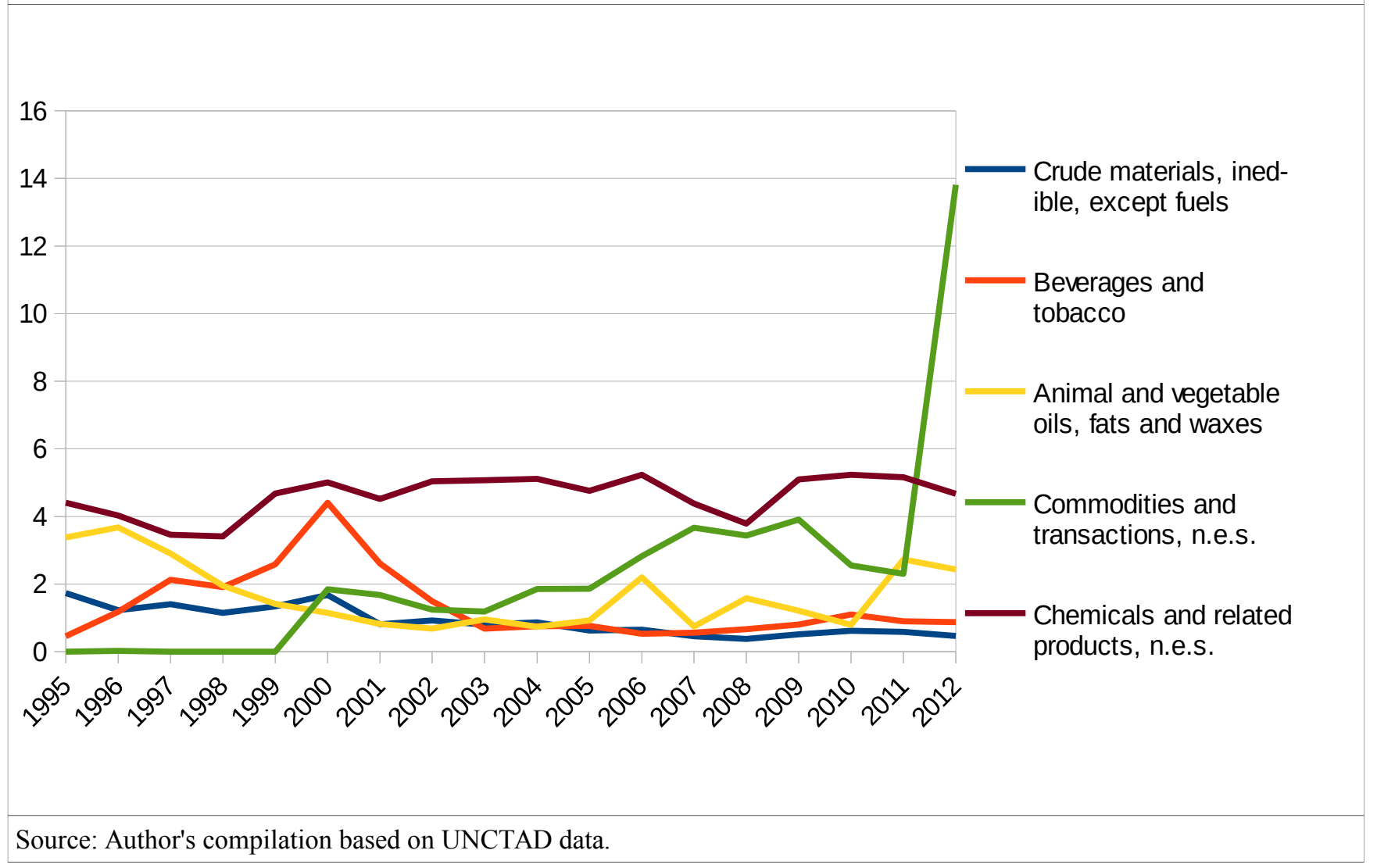

Figure B18: Distribution of Exports to Arab Countries 





Figure B19: Distribution of Imports from Arab Countries



Source: Author's compilation based on UNCTAD data.

Figure B20: Distribution of Imports from Arab Countries 


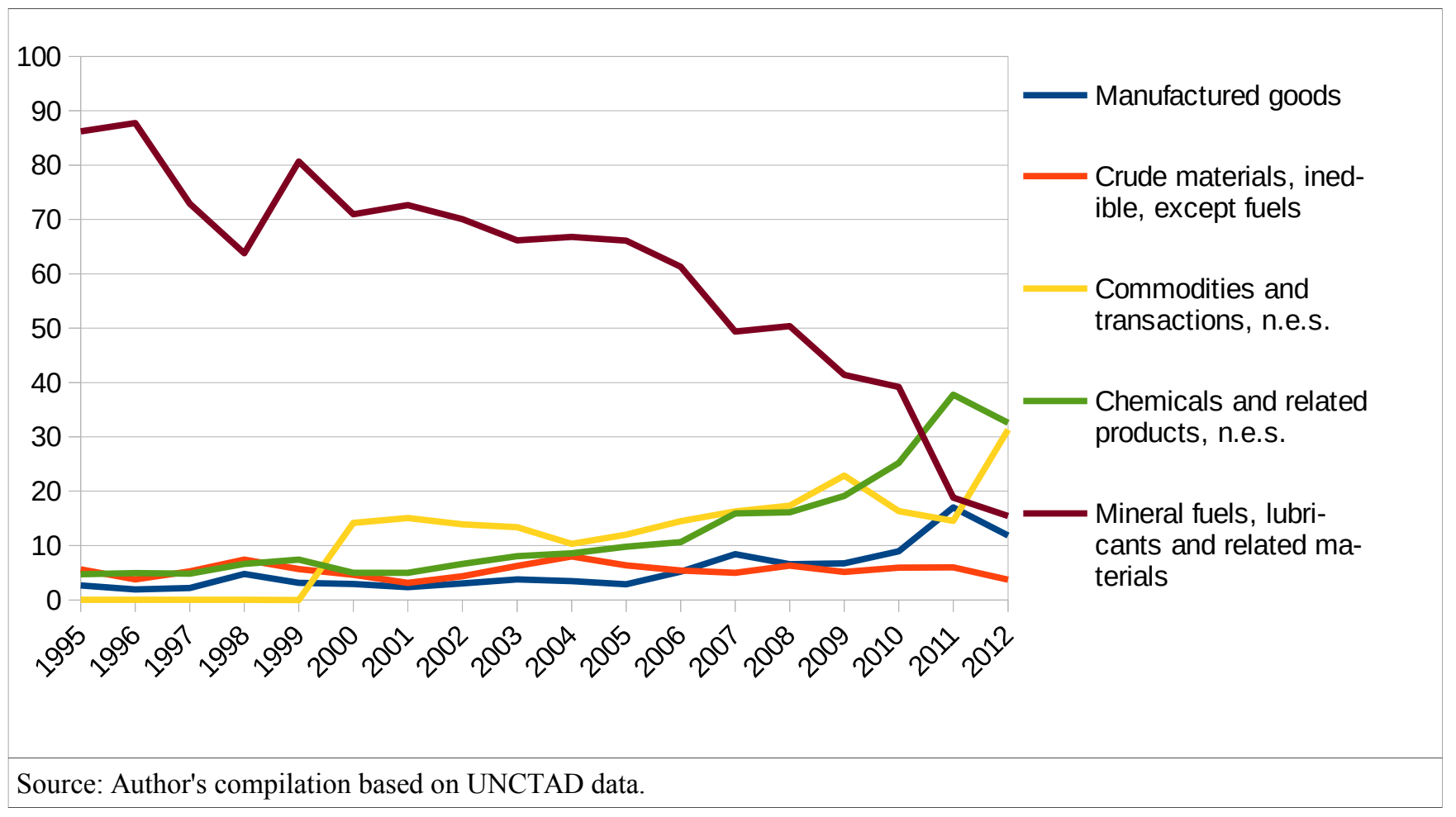

